\title{
BUSINESS ENVIRONMENT AND LABOR MARKET OUTCOMES IN EUROPE AND CENTRAL ASIA COUNTRIES $^{1}$
}

\section{Paloma Lopez-Garcia ${ }^{2}$}

World Bank Policy Research Working Paper 3885, April 2006

The Policy Research Working Paper Series disseminates the findings of work in progress to encourage the exchange of ideas about development issues. An objective of the series is to get the findings out quickly, even if the presentations are less than fully polished. The papers carry the names of the authors and should be cited accordingly. The findings, interpretations, and conclusions expressed in this paper are entirely those of the authors. They do not necessarily represent the view of the World Bank, its Executive Directors, or the countries they represent. Policy Research Working Papers are available online at http://econ.worldbank.org.

\footnotetext{
${ }^{1}$ This paper was prepared as a background paper for the ECA regional study Enhancing Job Opportunities: Eastern Europe and the Former Soviet Union

${ }^{2}$ Bank of Spain. Research Department, Alcala 48, 28014 Madrid. Correspondence to paloma.lopezgarcia@bde.es
} 


\begin{abstract}
New firm entry has been proven to be fundamental for job creation in the transition economies. Hence, the urge to reform the framework in which firms operate. This paper aims to improve our understanding of the business environment of the ECA countries as well as to assess which of the institutions that shape it are most important for labor market performance. To achieve that aim, the paper groups the institutions into those affecting firm entry and those affecting business survival and growth and proceeds to construct indicators able to summarize them. Next, the paper analyzes the impact of the business environment institutions on the employment generated by the private sector of the countries, proxied by the service employment rate. The regression analysis uses an unbalanced panel of 28 ECA countries over 14 years: from 1988 to 2002. Recent literature on the labor market performance of the OECD countries argues that what matters for employment is the interaction between institutions and shocks. Accordingly, the explanatory variables used in the regression are the interactions between the transition shock suffered by the ECA countries and each of the business environment institutions previously defined. We find that the access to finance is the most important institution across all ECA countries. The development of the financial sector can explain about $40 \%$ of the private employment creation in the European transition economies, according to the model. On the other hand, the poor access to finance in Bulgaria, Croatia, and above all, Romania, is the main factor behind their poor development of the private sector. Market regulation (credit and labor regulation), start-up costs and the tax burden are all found to significantly affect employment as well.
\end{abstract}




\section{INTRODUCTION}

\section{Firm creation is crucial for employment growth and development}

David Birch published in 1979 a ground-breaking study on the job creation potential of firms. He concluded that small and, above all, young firms in the US created 8 out of 10 new jobs. As a result of this revolutionary finding, policy-makers are increasingly aware of the importance of the creation of new firms for the aggregate employment. One example of this awareness is the commitment set by the European Union at its Lisbon European Council in March 2000 to boost entrepreneurship (or firm entry) as part of its strategy to transform its economy and build a future economic and competitive strength.

The importance of new firm creation as a source of new jobs is even larger in a situation of large reallocation of workers and jobs across sectors. New firms in the expanding sector need to absorb workers released from firms in the declining sectors. If new firm creation is not enough, unemployment will rise. It has been estimated for the case of Italy, a good example in the European context of a country that has undertaken large displacement of workers from the agriculture and industry sector to the service sector, that the contribution to unemployment of barriers to entrepreneurship doubled when the worker reallocation was taken into account. ${ }^{3}$

During the last decade, European and Central Asian countries (ECA) have suffered as well large displacement of workers. Most of large enterprises have downsized during the transition: they have reduced labor hoarding and shed redundant labor so as to reach the economically efficient size. As a result, the average firm size has decreased, and become closer to that in market economies. But if the average firm size decreases, the only way to increase employment is through a faster pace of firm formation. There must be more firms - firm density needs to increase - in order to offset the smaller firm size.

\section{The importance of the business environment for firm entry}

Firm entry and expansion depend on the quality of business environment. The business environment or investment climate comprises institutions and policies that affect firm entry on the one hand, and institutions and policies that affect the survival and growth of new firms on the other hand.

Institutions that affect firm entry, according to the empirical and theoretical evidence, are the administrative burdens on firm creation (start-up costs), the costs of going bankrupt (exit costs) and the access to finance (where both the availability and the cost of finance for new and small firms are included).

\footnotetext{
${ }^{3}$ See Lopez-Garcia, Paloma (2002): Labour Market Performance and Start-up Costs: OECD Evidence”, Centre for Economic Performance (LSE) Discussion Paper 565
} 
The main set of policies and institutions that might have an impact on the survival and growth of recently created firms is the government interference in the day-today operations of business. That includes a wide range of factors, going from business regulations to corruption. They can be grouped for operational purposes in four categories: legal system, market regulations, size of government and corruption level. The tax system, both the tax burden and tax regulation, is also consistently reported as hampering firms' survival and growth.

\section{The impact of the investment climate on labor market outcomes}

It has been estimated using data for a large group of ECA countries from the early 1990s and multivariate regression analysis that the most important components of business environment affecting employment outcomes are the access to finance, market regulations and the start-up costs. The tax burden is especially important in the new EU members. The legal system and corruption appear to be important in those countries less advanced in their transition towards a market economy.

The analysis presented in this paper suggests that reforms aimed at making it easier and cheaper for new firms to access the required finance to start and expand a business might help job creation, through firm entry, in the new private sector of the ECA economies. Lowering the administrative burdens to start a business and deregulating the credit and labor markets have also a positive impact on employment.

The paper is organized as follows. The next section introduces briefly the institutions shaping the investment climate of a country. A preliminary analysis, using bivariate correlations and graphs, of the impact of the investment climate on the labor market is carried out in section II. The graphical analysis is followed by a multivariate analysis that allows a more precise estimation of the effect of each institution after controlling for a number of variables. Lastly the business environment within the ECA regions is analyzed. The objective of this analysis is to facilitate the identification of idiosyncrasies of each region, in order to improve the investment climate and hence to increase firm density and job creation. 


\section{MEASURING THE BUSINESS ENVIRONMENT}

What do we understand by business environment? The life cycle of a firm resembles that of a person. Firms are born; if they survive birth they grow, or live at a comfortable small size; and eventually they die. This simplistic view of the entrepreneurial process can help to classify the regulations, institutions and policies that shape the business environment of one country or region into those that affect mostly the entry, and those that have an impact on the survival and growth of a firm.

Of course life is more complicated, and factors that have a direct impact on the dayto-day operations of a firm, like the tax level, can have an impact on the entry decision because expected profits net of taxes might simply not compensate the risks undertaken by an entrepreneur. Other factors affect all stages of the firm cycle, therefore it is difficult to assess whether they belong to one or the other category. One example is corruption and red tape which make it costly and cumbersome to register a business and even more so to run it every day. Lastly, there are factors that do not fit in any of the categories suggested above. One of those factors is the bankruptcy law, which determines the direct cost of exit.

Keeping all those caveats in mind, the classification of institutions into different groups, loosely related to the stages of the entrepreneurial process, helps analyzing systematically the context in which firms are created and operate and its impact upon employment performance.

What follows is a brief discussion of each of the institutions that make the investment climate of a country. Although not exhaustive, the list of institutions provided is the outcome of the theoretical and empirical research carried out in the field of entrepreneurship. For a detailed description of the variables used to measure each of those institutions, please refer to Appendix 2.

\section{I.1. What affects the entry decision of entrepreneurs?}

The two main barriers to firm creation are the administrative burdens on firm creation and the access to finance. Those two are the main obstacles identified by Europeans, according to a periodical empirical study on Entrepreneurship carried out by the European Commission. ${ }^{4}$

\section{Administrative burdens on firm creation}

Administrative burdens on firm creation might have a large impact on the labor market performance of transition economies. Burdens on firm creation have been proven to prevent job creation in the service sector, where firms are smaller and job creation depends heavily on new firm entry. Hence, in a situation of large job destruction in other economic sectors, high administrative costs on firm creation can result in high unemployment. That was the case in Spain and Italy, where many jobs

\footnotetext{
${ }^{4}$ Flash Eurobarometer 134 "Entrepreneurship”. Done by EOS Gallup Europe upon request of the European Commission (DG XXIII), 2000, 2001 and 2002. In general, around 70\% of the people surveyed agree that the existing administrative procedures are complex and $76 \%$ claim that the main problem is lack of available finance.
} 
were destroyed in the agriculture sector over the last decades and the service sector did not generate enough jobs to absorb those displaced workers.

During the last decade, transition economies have also experienced a large worker and job reallocation due to the significant destruction of jobs in privatized companies and in the agriculture and over-staffed industrial sector. Hence we might expect high start-up costs to prevent firm entry and therefore increase unemployment.

Administrative burdens on firm creation refer to issues such as the number of procedures to register a business, the time and cost to undertake those procedures and the minimum capital requirements. However, as one can see in Box 1, other "unofficial burdens" such as informal payments or bribes required to get business licenses, can have also a large impact on the administrative entry barriers for new businesses.

\section{Box 1: What the official data on entry barriers do not show: the case of Romania}

Measurement matters. Different ways of measuring the same concept can yield different conclusions. The case of the start-up costs in Romania is a good example of that.

According to objective data from the World Bank, opening a business is easy in Romania: no more than 6 procedures are required to start a business, one can go through the process in less than a month (37 days in average in Europe) and the cost of the process and minimum capital requirements are among the lowest in the ECA countries.

However, when one looks at similar indicators of start-up costs based on subjective opinions, in this case of managers of large corporations, the situation is quite different. According to the evaluation given to the sentence "Starting a new business is generally easy" by the Global Competitiveness Report, Romania is one of the countries where starting a business is most difficult (figure 2.1).

The differences between the objective and subjective indicators could lie on the existence of wide-spread corruption in Romania, which is not included in any of the objective measures of start-up costs compiled by the World Bank. Indeed, when one looks at the GCR's evaluation of the sentence "irregular additional payments connected with import and export permits, business licenses, exchange controls, tax assessments, police protection or loan applications are very rare" (figure 2.2), Romania along with Turkey occupies the last position.

Hence objective indicators have to be complemented sometimes with subjective impressions and anecdotal evidence to get a complete picture of the business environment in each country. 


\section{Access to finance}

Another large concern of would-be entrepreneurs is access to finance. External finance, that is, resources other than the entrepreneur's own savings, is often necessary to start a business --one needs to rent office space, buy computers, or maybe test a prototype. External finance is also important to expand an existing business.

However, entrepreneurs have generally difficulty securing bank loans. The reason is that banks want a positive track record and collateral -which new firms generally do not have.

The scarcity of seed capital is even more acute in transition economies. A study of the entrepreneurial activity in Croatia ${ }^{5}$ found out that business opportunities were exploited mostly by high-income individuals. This finding suggests that potential entrepreneurs are credit constrained. The reasons are the high cost of credit, large collateral required by banks, or lack of credit available to the private sector. Data on those indicators have been used to construct an index of access to finance in each of the countries under analysis. For more details, please refer to Appendix 2.

The lack of development of the financial sector in many of the ECA countries is the consequence of a combination of factors: the lack of proper regulation of the banking sector, the lack of competition in some countries because the State still holds majority ownership in large banks, the low deposit rate, due to the mistrust of the banking sector, and the risk-aversion of banks before new or small businesses among others.

Although another possible source of finance is risk capital, venture capital funds are invested mainly in the expansion phase of high growth businesses, ignoring the initial stages of firms all together. Besides, the development of venture capital goes hand in hand with that of the stock markets, which are still underdeveloped in transition economies.

\section{Exit costs}

Bankruptcy costs, and the more elusive stigma of failure, might have a large effect on the entry decision of would-be entrepreneurs. That is the reason why we have included the exit costs in the section dedicated to factors preventing firm entry.

The importance the of bankruptcy costs as an explanatory factor of entrepreneurial activity is based on the observed large differences in the perception and the cost of failure between Europe and the US. While around 50\% of the Europeans surveyed in an empirical study affirmed that "one should not start a business if there is a risk it might fail”, only $25 \%$ of North-Americans thought the same. ${ }^{6}$ Among the risks most

\footnotetext{
${ }^{5}$ Slavica Singer et al. (2003): What makes Croatia a (non) entrepreneurial country? Global Entrepreneurship Monitor 2002.

${ }^{6}$ Flash Eurobarometer 134 "Entrepreneurship”. Done by EOS Gallup Europe upon request of the European Commission (DG XXIII), 2000, 2001 and 2002.
} 
feared were the risk of losing one's property and the risk of going bankrupt; hence the bankruptcy law might play an important role in preventing firm creation.

Although the cost of failure is difficult to measure, the World Bank has gathered information on the time and cost of going through an insolvency process in each of the countries under analysis. For more details, please refer to Appendix 2.

\section{I.2. Which institutions and policies affect the survival and growth of new firms?}

Entrepreneurs face many obstacles. Complying with administrative regulations and their related costs is one of the most significant burdens. But also the red tape, the degree of flexibility of the labour market or the tax burden constraint business performance.

Institutions affecting the day-to-day operation of businesses are important for two reasons: first, they affect the expected benefits and costs from creating a firm, which are taken into account by would-be entrepreneurs. Moreover, even if they do not prevent entrepreneurship, they might force entrepreneurs into the informal economy, where their prospects of prospering and growing are low. Second, once the entry decision has been taken, they have an impact on survival and expansion -and therefore on job creation-- of existing businesses.

\section{Government interference}

The government imposes price controls and cumbersome regulations, carries out over-inquisitive tax inspections and still holds or controls fundamental sectors of the economy. Another important set of factors may consist in the actions governments are not taking. Some examples are poor enforcement of the law, poor protection of property rights and laissez-faire with respect to bribes and corruption.

For operational purposes, data on government interference has been organized around four big issues: the quality of the legal system, market regulation (which includes credit and labor market regulations), size of government and corruption. Please refer to Appendix 2 for detailed definitions of each of those components.

\section{Box 2: Efficient but not independent judicial systems; the cases of Russia and Turkey}

The quality of the legal system comprises aspects of the efficiency of courts. But it also should take into account the independence of the judicial system from political and economic agents and the protection to property rights.

The World Bank offers information on issues related to the efficiency of courts to enforce contracts. They are derived from questionnaires answered by attorneys at private law firms. According to that information, courts in Russia and Turkey are more efficient than the European average when dealing with disputes about contract enforcement (figure 2.3). 
However, when one looks at the independence from the government, impartiality and integrity of the judicial system (all provided by the 2003 Annual Report of Economic Freedom of the World, a compilation of objective and survey data), those two countries, precisely, score last in the ECA countries ranking (figure 2.4).

Hence, it is not enough to look at the efficiency of the courts to assess the quality of the legal system. One has also to explore the independence of the courts and the protection to property rights to get a complete picture.

\section{Tax system}

Apart from the level of taxes, potential entrepreneurs may be deterred by the frequency of changes in the fiscal law, which enhances business' uncertainty. Together with the frequent and over-inquisitive tax inspections, this practice results in entrepreneurs spending the bulk of their resources, be them money or time, trying to comply with the tax law rather than to business planning.

Hence both the tax burden and the tax law (transparency and predictability) are important factors affecting the survival and growth of business.

\section{Summary}

The main sets of institutions affecting the entry of new firms are: the administrative burdens on firm creation, the access to finance, and the exit costs.

Survival and growth depend on two large set of institutions. The first set deals with the interference of governments into the day-to-day business operations. It includes a wide range of factors, going from business regulations to red tape. They have been grouped in four categories: legal system, market regulations, size of government and corruption (and informal economy, very related to the latter).

Finally, the tax burden and unpredictability of the tax law have also been identified as important determinants of the probability of survival and growth of new companies. 


\section{THE BUSINESS ENVIRONMENT AND THE LABOR MARKET PERFORMANCE}

Do countries with better business environment have better labor market performance? Which institutions are most important for a good employment record? Those are the two very important questions this section attempts to shed light on. We proceed in two stages. First, we perform a graphical analysis of the data in order to explore possible correlations between the investment climate and labor market outcomes. Second, multivariate analysis is used to estimate the contribution to employment of the different institutions considered here.

\section{II.1. A first approximation to the data: bilateral correlations}

The first approximation to the data comes in the form of simple scatter-plots of the different dimensions of the business environment previously described against service employment rate, purged from the GDP per capita. ${ }^{7}$ The rationale is that service employment rate is a good proxy for employment created by the new private sector since it is the only sector increasing its share of employment in all transition countries. It is also where new business opportunities can be mostly found. To separate the effect of economic development from the direct effect of the business environment institutions on the growth of the service sector, we use a corrected measure of service employment rate which controls for the GDP per capita. ${ }^{8}$

\section{Box 3: Why do we use service employment instead of total employment rate as a labor market indicator?}

The focus of this paper is the employment generated by the new private sector. Hence the service employment rate is a better labor market indicator than the total employment rate.

The reason is that total employment is the sum of employment created by the public and by the private sector. Countries with a large public sector have, in general, a large total employment rate, which can be compatible with a bad business environment. That is because public employment does not respond to any of the business environment institutions we are interested on in this paper.

\footnotetext{
7 The service employment level comes from the ILO database. It is the sum of the employment in the following sectors: wholesale and retail trade; repair of motor vehicles, motorcycles and personal household goods; hotels and restaurants; transport, storage and communications; financial intermediation; real state, renting and business activities. Hence we do not include employment in public administration and defence, employment in education, health and social work and other community, social and personal services. The reason is that employment in the latter sectors does not come generally from private initiative, which is the focus of the paper. In most cases data are from Labour Force Surveys, which ensures comparability. However, for the following set of countries the data source is official estimates: Azerbaijan, Bulgaria, Kyrgyzstan, and Uzbekistan. The service employment rate is calculated as percentage of working age population (15-64).

${ }^{8}$ To control for the economic development we run a regression of the service employment rate against the GDP per capita. The residuals from that regression represent the service employment rate NOT explained by the development of the economy. The residual is what we call the "service employment rate controlled for GDP per capita.”
} 
In order to illustrate that claim, an index summarizing the government interference in the economy has been plotted against total and service employment rate (figures 3.1 and 3.2). As one can see, the negative impact of the investment climate indicator on service employment is much larger than the impact on total employment rate.

Hence, service employment rate is a better proxy to private sector employment. It will be used, along with the unemployment rate, as labor market indicator throughout the paper.

\section{The firm entry environment}

The previous section considered three groups of institutions that could size the entry barriers for entrepreneurs: the administrative burdens of firm creation, the access to finance, and the exit costs. Out of the three entry barriers, access to finance seems to be the most correlated to service employment (figure 3.3). ${ }^{9}$

The access to finance index is a summary of data on the cost of credit, collateral required, credit to private sector, and protection to creditors (for details please refer to Appendix 2). Of all those variables, the most important one for employment is the real interest rate or cost of finance (figure 3.4).

If the real interest rate was the only variable explaining service employment, it would be able to explain about $30 \%$ of the variation across countries, after controlling for the degree of economic development.

\section{The firm operating environment}

Government interference in the economy ranges from burdensome regulation in the credit and labor markets to the efficiency of the legal system. The summary indicator of government interference is strongly, and negatively, correlated to employment performance. The graph below plots the summary index against service employment rate controlled for GDP per capita (figure 3.5).

In particular, the two sub-dimensions of the government interference index that harm employment outcomes the most are the poor quality of the legal system and cumbersome market regulations. The quality of the legal system includes both the efficiency of the judicial system to enforce contracts as well as its independence. Market regulation includes credit and labor market regulations. The former refers to issues such as the percentage of deposits held in privately owned banks, the degree of competition from foreign banks and interest rate controls. Labor market regulation considers hiring and firing practices, impact of minimum wages, unemployment benefits, and union coverage.

\footnotetext{
${ }^{9}$ Unless stated otherwise, the labor market indicators used in the scatter-plots presented in this section correspond to the year 2001; it is the most recent year with a reasonable number of observations. All business environment indexes have been re-scaled so a higher number indicates more of whatever the index reflects: start-up costs, access to finance, exit costs, government interference and so on.
} 
In summary, access to finance and government interference, particularly market regulation and the quality of the legal system, seem to be the most important aspects of the investment climate as for employment outcomes.

However, bilateral correlation analysis can only give a rough idea of the impact of the investment climate on labor market outcomes.

\section{II.2. Regression analysis}

A more rigorous analysis of the impact of investment climate on employment requires multivariate regression modelling. Multivariate regressions have an advantage over bilateral correlations, namely, one can control for a range of variables. Hence the average impact of better access to finance on employment performance, for example, can be estimated, given the value of the rest of the dimensions of the investment climate. One can also control for country effects, that is, for specific characteristics of each country that are constant over time, and are not explicitly taken into account.

\section{Unemployment theories}

While there is wide consensus on the determinants of cyclical unemployment --namely aggregate demand and aggregate supply fluctuations caused by the demand and supply shocks hitting the economy -- the determinants of the natural rate of unemployment have been at the core of the research agenda of labor economists over the last three decades.

In the 1970s the discussion about the determinants of unemployment was dominated by a "shock story." Supply shocks of the 1970s and 1980s and restrictive macroeconomic policies to fight inflation were blamed for unemployment. But shocks across countries are not likely to vary enough to explain, first, the persistence of high unemployment and, second, the observed differences in labor market performance.

The focus then moved to institutions, ignoring shocks altogether. But those institutions in many countries have not varied enough along time to explain properly the unemployment evolution over the last decades.

In consequence, labor economists are turning lately to explanations of unemployment that use the interaction between shocks and institutions: shocks can explain the evolution along time of unemployment, and institutions the differences across countries. The argument is that the institutional setting of a country shapes the impact that otherwise similar shocks have upon the labor market performance. ${ }^{10}$

\footnotetext{
${ }^{10}$ The first economists to propose this idea were Michael Bruno and Jeffrey Sachs (M. Bruno and J. Sachs (1985): Economics of Worldwide Stagflation, Cambridge: Harvard University Press). In their 1985 book, The Economics of Worldwide Stagflation, they focused on the interaction of the 1970s oil price shocks with the nature of collective bargaining. But it was actually after the publication in 2000 of Blanchard and Wolfers' model of equilibrium unemployment that the interaction of shocks with institutions became a popular explanation among labor economists for the unemployment evolution of developed countries.
} 
We will use this framework, the interaction of shocks and institutions, to explain the recent evolution of the labor market in the ECA countries.

\section{The regression model}

To capture the interaction between shocks and institutions, the simplest model is as follows:

$u_{i t}=c_{i}+d_{t}\left(1+\sum_{j} \gamma_{j} X_{i}^{j}\right)+\epsilon_{i t}$

where $u$ is the unemployment or employment rate in country $i$ at time $t, c$ are the country dummies, $d$ are time dummies, that is, unidentified shocks assumed to be equal across countries ${ }^{11}$, and $X$ is the time-invariant value over the period of the institution $j$ in country $i$.

What matters in the estimation is not the value of the shock or the institution but the interaction between both of them. This is the most general specification since no specific shocks are imposed; we only assume that a number of shocks over time, of equal dimension across countries, have hit the economies. Hence, it allows isolating the impact of the (different) institutions from that of the shocks.

The next step in the analysis will be to identify the shock, that is, to allow the shock to be specific to each country. Transition economies have been hit by a similar shock over the last decade, namely, a transition shock. But their labor markets have reacted differently. Some countries have managed to go through with low unemployment while others have ended up with a poor employment score. Why is that? The answer is that the impact of the shock depends on whether the institutions of the country are more or less friendly to employment creation.

Substituting the time dummy in (1) by the transition shock, which differs across countries, we can estimate how the different institutional framework of each country has facilitated or obstructed the creation of a new private sector after the fall of the communism.

\section{Data}

To estimate the coefficients corresponding to each of the institutions in model (1), we use an unbalanced panel of 28 ECA countries over 14 years: from 1988 to 2002. Unfortunately we have only one year of information for most of the institutions introduced in section 2. It is unfortunate because it would be interesting to explore how the reforms introduced in the business environment over the last decade have affected the capacity of the economy to respond to shocks. Given the data constraint, we have to assume that the institutional framework in which firms have operated

\footnotetext{
${ }^{11}$ The first period is left out so it becomes the constant. Therefore the country dummies can be interpreted as the unemployment in the first period.
} 
over the period of analysis can be adequately summarized by the set of indexes introduced in section 2.

Until very recently, the only institutions considered to affect unemployment were labor market institutions such as unemployment benefits or employment protection legislation. Those institutions are important, among other things, because they affect the expansion and contraction of established firms, which have an important impact on unemployment.

But apart from the expansion of established firms, there is another source of job creation, namely, the birth of new firms. The few statistics that we have show that between one third and one fourth of new jobs are created by new, genuinely private, firms in the ECA countries. Hence new firm creation is a very important source of new jobs in the group of countries we consider.

The rate of creation of new firms, and therefore job creation, depends on those institutions that shape the business environment where firms operate, described in section 2 of this paper. We intend to explore the impact of each of those institutions on the labor market.

The list of institutions considered in the regression model is as follows:

- Administrative burdens on firm creation (start-up costs)

- Cost of going bankrupt (exit costs)

- Access to finance (cost and availability of finance)

- Quality of the legal system (efficiency and independence of courts)

- Market regulations (credit and labor market regulation)

- Corruption (perceived corruption level, from Transparency International)

- Tax burden (tax revenue as percentage of GDP)

For a detailed account on the construction of indexes able to capture those institutions, please refer to Appendix 2.

The ECA countries have been hit by a major shock over the last decades: the fall of the communism regime and transition to a market economy. We will use the EBRD transition index to size the shock across countries and to follow its evolution along time.

The EBRD transition index aims to reflect each country's moment in the transition towards a market economy. Hence it deals, among other things, with issues such as the emergence of a private sector, the size of the government and so on, which are some of the indicators of the business environment we have considered in section 2 . Therefore we could have some multicollinearity problems in the regressions, that is, relationship between explanatory variables which could distort the estimation results. $^{12}$

\footnotetext{
${ }^{12}$ However, even so, the regression estimates will still be unbiased and consistent.
} 
Partly due to this problem, partly to be able to isolate the impact of institutions from that of the transition shock on the service employment rate, we proceed in two stages:

1. We first estimate the model assuming that all countries have been hit by a shock of the same magnitude. Hence differences across countries are solely due to differences in institutions.

2. Then we allow the shock to be of different magnitude in each country in order to estimate the impact of the interaction between the transition shock and the business environment on the development of the service sector. However, we must take the estimation results from this last exercise with caution due to the multicollinearity problem mentioned above.

\section{Estimation results of multivariate analysis}

To isolate the impact of the institutions on the service employment and unemployment rate from the effect of the transition shock, we begin assuming that the shock has been the same across countries. Hence, if labor market outcomes are different that is solely due to differences in investment climate.

The results of the estimation of the regression are shown in Table 1 below.

Imagine we had a representative country where the investment climate was exactly the average across ECA countries. Then the shock (our proxy for the transition shock) would explain an increase in service employment (different from the natural increase in service employment due to economic development) of 0.8 percentage points. The unemployment rate in such a representative country would increase almost 1 percentage point.

But service employment and unemployment have not changed equally across countries after the shock. Since we are assuming, for the moment, that the shock is the same for all countries, different labor market outcomes must be due to differences in the investment climate. Business environment institutions that impede the economy to readjust after being hit by a shock might increase the negative impact of that shock. That is what the coefficients of the rest of the variables are telling us.

The two most important variables explaining service employment are the access to finance and credit and labor market regulation. The importance of those two variables is confirmed by the results of the unemployment regression, although one must keep in mind that institutions that shape the business environment have a smaller impact on total employment or unemployment than on the service (or private) sector.

The next variable in importance is the administrative burdens on firm creation. Administrative burdens on firm creation decrease the service employment rate. As expected, administrative burdens on firm creation have less of an important effect on total employment and unemployment. The reason is that they do not affect public sector employment. 
Across countries with a similar degree of economic development, those with a lower tax burden enjoy higher service employment rates and lower unemployment. It is important to control for the degree of economic development, otherwise, and given that more developed economies have in place better mechanisms to collect taxes and a smaller informal sector, the impact of the tax burden could not be properly estimated.

The existence of an efficient and independent legal system and the perceived corruption level matter for employment outcomes, but their impact cannot be separated from the impact of economic development. The quality of the legal system increases, and corruption decreases, as the country develops. Hence their effect on the service employment rate is accounted for already by the economic development variable. The importance of the corruption level in explaining unemployment, in table 1, seems to confirm that hypothesis, since in that regression the economic development of the country has not been explicitly controlled for. To further confirm it, we have also run the service employment regression without controlling for GDP per capita and got a significant negative impact of corruption levels on service employment rate.

\section{The contribution of the investment climate to the change in service employment and unemployment for selected ECA countries}

What do those coefficients mean? Or in other words, what is the size of the impact of those variables upon employment outcomes?

The resulting contribution of each of the investment climate institutions to the service employment growth (corrected by GDP per capita) can be calculated from the estimation results shown above. Table 2 shows the results of that calculation for the new EU transition economies (with the exception of Estonia due to a lack of data).

The way of reading the table is the following. The first row reflects the actual change in service employment (corrected by GDP per capita, or not explained by economic development) over the period of analysis. All countries have experienced a rise in service employment, above the one implied by economic development, but Lithuania where the service employment is lower than the one we should expect given its GDP per capita. The average increase in corrected service employment over the period is of 1.08 percentage points.

The second row shows the change in service employment predicted by the model, given the impact of the time shock, country-specific effect, and investment climate in the country. In average (last column) the model performs quite well, which means that the set of institutions conforming the business environment is able to explain the employment performance in the private sector.

Recall that if all countries had the same investment climate, set at the cross-country average, the impact of the shock on the labor market would be the same because the shock is assumed to be equal across countries (in table 2 that is not the case because 
the period of analysis is not the same for all countries given data constraints). If the actual impact of the shock on labor market performance in different ECA countries is different is because institutions vary across countries.

Start-up costs are higher than the cross-country average in all countries in table 2 but in Latvia, Lithuania and Slovenia, which explains its average negative contribution to the development of the service sector (in average it contributed $-0.13 \%$ to the predicted average increase in service employment: 1.09\%). Hungary, where the cost of starting a company is well above the ECA average, is the only country strongly penalized by the existing high start-up costs. However, given that the estimated coefficient of start-up costs in table 1, although significant, is quite small, the average contribution of that institution is all in all negative but small.

As we saw in the graphical analysis, the main contributor to employment creation in the private sector is the access to finance. The fact that Hungary and Poland have both a better access to finance than the average in ECA countries can explain their good private employment performance. Slovenia, another country where the access to finance is quite easy for entrepreneurs, would have performed much better if it was not because of the very strict labor market regulation (one of the most rigid across all ECA countries) and high tax burden. Note that, in average, access to finance can explain about $40 \%$ of the whole increase in service employment predicted by the model (that is, it explains 0.44 of the total $1.09 \%$ increase in service employment predicted by the model).

Market regulation includes both credit and labor regulation. It is a very important variable to explain the good performance of Hungary, in spite of the high start-up costs, and the bad performance of Slovenia which, as mentioned before, has one of the strictest labor codes in the region.

In summary, the institutions that have contributed the most to the development of the service sector, on average, are in this order: the access to finance for entrepreneurs, the low tax burden, low start-up costs and market de-regulation.

Table 3 shows the same type of exercise for the next wave of accession countries (Bulgaria, Romania and Croatia), as well as Ukraine and Russia.

The model is less powerful predicting the actual service employment change in the next wave of accession countries. Surely that is due to the fact that corruption and the quality of the legal system play far more an important role in this group of countries than they did for the new EU members. One possible indication of that is that the model fits best the case of Croatia, the country with the best legal system and lowest corruption level of the three future EU members. However, in average (considering all countries in the sample) corruption and the quality of the legal system were not significant, hence they are not included in the table.

Romania is the only country of the three with a service employment change smaller than the one we should expect given its GDP per capita. The model points quite clearly to the very poor access to finance in the country as the institution to be blamed. Indeed, Romania scores last in the access to finance ranking due to its very high real interest rates, high collateral and, above all, lack of protection to creditors 
(according to the World Bank, Romania is the only country with the lowest possible score in that respect).

Bulgaria has already undertaken reforms to lower the start-up costs, reduce corruption and lower the real interest rates as well as increase creditors' protection, all of which explains the better than average performance of that country.

In summary, the institutions that have had a larger impact on the service sector within this group of countries, on average, are in this order: the access to finance, start-up costs, market regulation and tax burden. Note that the tax burden was the second institution in importance within the new EU members while here it is the last variable in importance. The reason, as mentioned somewhere else, is that taxes are a burden only in those countries with a developed fiscal system and a small informal sector. Market regulation seems, on the other hand, to be a larger problem for the accession countries than for the new EU countries.

We do not have data on the actual service employment change in Russia and Ukraine. The change predicted by the model is larger in Ukraine than in Russia. These two countries are particularly comparable because the time shock refers to the same period. So the differences in predicted employment are only due to the different institutional setting. Although start-up costs are lower in Russia than in Ukraine, the access to finance and, above all, the market regulation (recall, credit and labor market regulation) are worse. Market regulation is actually the key to explain the relatively worse performance of Russia.

The main problems of Russia and Ukraine, on average, are the market regulation, access to finance and start-up costs, in this order. The less developed tax-collecting system implies that the tax burden is theoretically lower in these two countries, which has benefited (according to the model) employment.

Table 4 below puts together the ranking of institutions according to their impact on private employment by ECA region.

Some regularities emerge. First, the market regulation (credit and labor regulation) becomes more important as countries are further away from a market economy. That makes sense since new EU countries, maybe with the exception of Slovenia, have all undertaken structural reforms to deregulate their markets. Second, the tax burden becomes understandably a big problem in those countries with a proper tax administration and tax-collecting infrastructure in place. It is, obviously, a secondary problem in countries where the informal sector is large or tax fraud extended.

Third, access to finance is, with little changes, the most important institution to explain employment outcomes. The development of the financial sector and easy access to finance can explain about $40 \%$ of the private employment creation, according to the model, in European transition economies. On the other hand, the poor access to finance in Bulgaria, Croatia and, above all, Romania is the main factor behind the poor development of the private sector in the future EU transition countries. 


\section{Substituting the common shock by the actual EBRD transition shock}

After estimating the model assuming a common shock across countries, which was considered a proxy for the transition shock, we re-estimate everything using instead the EBRD transition shock. Thus, the state of the transition process is now taken into account. Those countries further in the process are considered to have suffered a larger transition shock.

Given the econometric problems identified earlier in the section, the purpose of this exercise is solely to check whether the investment climate has a larger impact on the labor market performance of countries undertaking a large reallocation process due to the transition to a market economy.

Table 5 shows the contribution of the institutions to the increase in unemployment over the period 1992-2002 in Hungary, according to the common shock and transition shock regressions.

The unemployment rate in Hungary has decreased 3.5 percentage points over the period of analysis. Of the two models considered, the one where the transition shock is identified performs better.

The transition process Hungary has undertaken so far would have increased unemployment in a country with average institutions by 3.8 percentage points. But the particularly friendly institutional setting of the country explains that, instead, the predicted change in unemployment is of -2.1 percentage points. Why is that? The main reason is Hungary's developed financial market, with easy access to finance. It is also due to the lower than average government intervention in the economy.

What is really interesting from table 5 is that the importance of all institutions conforming Hungary's investment climate increase if the transition shock is taken into account. In other words, a friendly business environment is especially important in those countries where the private sector needs to create enough employment to compensate job destruction elsewhere in the economy, as it is the case in all transition economies.

\section{Summary}

Multivariate analysis points at the access to finance, market regulation and start-up costs as the main contributors to employment creation in the private sector and, hence, to a lower unemployment rate. However, when the actual contribution of the institutions to labor market performance is calculated for selected countries, different patterns emerge.

Within the new EU countries, easy access to finance for entrepreneurs and a low tax burden are the two variables that, in average, contribute the most to employment creation in the private sector. Then one has to consider in order of importance the administrative burdens on firm creation and credit and labor market regulation. 
The model fits worse the data of the next wave of accession countries (Bulgaria, Romania and Croatia) due to the importance of corruption and bad quality of the legal system in that set of countries. Those two variables are not considered by the model since, in average, they are not significant.

According to the estimations, the main problem for employment in the group of accession countries is, again, the access to finance. That is the main barrier to employment creation in the private sector. Start-up costs and market regulation follow in the list. The tax burden is quite low so its impact on labor market is still quite low (as opposed to the new EU countries).

Ukraine and Russia suffer in average from cumbersome market regulation, which is the main cause of their relative underdevelopment with regard to private employment. Next in line is access to finance and start-up costs. A large informal sector, corruption and poor mechanisms to collect taxes explain the low level of taxes, and therefore, positive impact of that variable on service employment.

Finally, the investment climate is yet more important if the transition shock is explicitly taken into account. The case of Hungary shows that when the transition shock is taken into account the estimated contribution of a well developed finance sector to the predicted increase in service employment increases by a factor of 2.4. In other words, a friendly business environment is especially important in those countries where the private sector needs to create enough employment to compensate job destruction elsewhere in the economy, as it is the case in all transition economies. 


\section{ASSESSEMENT OF THE BUSINESS ENVIRONMENT IN ECA COUNTRIES}

Given the importance of the business environment on labor market outcomes, the objective of this section is to facilitate the identification of idiosyncrasies of each ECA region in order to improve the investment climate and, hence, to increase firm density and job creation.

In order to proceed with the analysis we do a benchmarking exercise. As far as possible we also include in the rankings the European average (for country grouping please refer to Appendix 1) and the United States.

The indexes used to summarize the investment climate are the same that were used previously in the regression exercise. Please refer to Appendix 2 for details on their construction.

While the birth of new firms is critical for job creation, in many ECA countries starting a business is not easy. After all, in most ECA countries the start-up cost index is less favorable than in the US (where it is least costly to start a business) or in Europe. The EU transition economies fare best on this scale, especially the Baltic States. It is also relatively easy to start a new business in Ukraine and in CIS-7 although the index there is below UE average. Starting a business is most costly in most of the non-EU transition economies as well as in Belarus and Russia (figure 4.1).

According to our estimations, access to finance is one of the most important factors affecting firm births and expansion, and thus job creation. But in ECA countries access to finance is substantially more difficult than in EU15. Generally, access to finance is better in European transition economies (EUTE and OUT) than in CIS and Turkey. But even in EU transition economies obtaining a credit is considerably more difficult and costly than in EU15 (figure 4.2).

The second variable in importance with regard to employment performance is labor and credit market regulation. Excessive market regulation restrains business activity and is associated with less job creation. There is a lot of room in ECA countries to make their markets more liberal and thus to foster employment growth. In all ECA countries markets are more regulated than in the US, and in most of them more regulated than in EU15. Again, European transition economies, especially new EU members, tend to have less regulated markets than CIS and Turkey (Figure 4.3). Thus, given that excessive market regulation has been shown to limit job creation, and that markets in ECA tend to be overregulated, lessening the regulatory burden on business activity is yet another way to encourage job creation.

Corruption is closely related to excessive regulations, and it has been shown to be a severe obstacle to business formation and growth, as well as to job creation in some countries. Given that corruption looms large in ECA, its negative impact on employment is likely to be substantial. Even the EU transition economies, where corruption is least widespread among ECA countries, are perceived as much more corrupt than EU15. Corruption is a severe issue in non EU transition economies (including EU accession countries) as it is in Turkey, and is perceived as widespread in 
CIS (Figure 4.4). Fighting corruption and its sources is thus critical for encouraging job creation.

The tax burden has been shown to hamper employment creation mainly in the EU transition economies, where there are in place efficient tax-collecting systems and the informal sector is relatively small. Both the tax burden (figure 4.5) and tax regulation are regularly perceived by firm managers in ECA countries as one of the main obstacles for business (ICA Survey, World Bank). Hence, a predictable and transparent tax code as well as reasonable tax burden on new firms could help greatly new firm formation and survival.

Finally, firm expansion and job creation are supported by an efficient legal system. Such a system is only being developed in ECA. The legal structure and security of property rights in ECA lag behind those in the US or EU15. Expectedly, the legal system is most developed in EU transition economies, less so in other European transition economies, and least developed in CIS and Turkey (Figure 4.6). Strengthening the legal system: ensuring greater security of property rights, improving contract enforcement and improving the efficiency of dispute resolution will advance the investment climate and thus be conducive to employment generation. 


\section{CONCLUSION}

New firm entry has been proven to be fundamental for job creation in the transition economies. Hence, the urge to reform the framework in which firms operate. This paper aims to improve our understanding of the business environment of the ECA countries as well as to assess which of the institutions that shape it are most important for labor market performance.

To achieve that aim, we have first defined and quantified what we understand by business environment. For operational reasons we have grouped the institutions affecting entrepreneurship into two groups: those institutions affecting firm entry and those affecting business survival and growth. Indexes combining diverse information for each of those institutions were constructed. Accordingly, firm entry conditions depend on the start-up and exit costs as well as on the access to finance. Firm survival and growth depend on the size of the government, ability of the legal system to enforce contracts and protect property, market regulations and corruption. The tax burden was also considered to have an impact on the day-to-day operations of business.

After defining what we understand for business environment, the next step was to analyze the relationship between its different dimensions and labor market performance. Scatter-plots were drawn to get a first impression of the relationships. We realized that no clear patterns could be established between the different institutions affecting the business environment and the employment and unemployment rate. The reason was the large share of public employment in some countries that, of course, was not responding to the business environment conditions. For that reason, we calculated the service employment rate and considered it a proxy to the employment created in the new private sector. The relation between the institutions and the service employment rate were remarkable.

To control for other variables and estimate the impact of each of the institutions on the labor market performance, we run multivariate regressions using the interaction of the institutions with the transition shock as explanatory variables. We aimed to find whether countries with a friendlier business environment were able to go through the transition process with a better labor market performance.

The results of the multivariate analysis pointed at the access to finance, market regulation and start-up costs as the main contributors to employment creation in the private sector and, hence, to lower unemployment rate. However, when the actual contribution of the institutions to labor market performance was calculated for selected countries, different patterns emerged.

1. Within the new EU countries, easy access to finance for entrepreneurs and a low tax burden are the two variables that, on average, contribute the most to employment creation in the private sector. The next institutions in order of importance are the administrative burdens on firm creation and credit and labor market regulation.

2. The model fits worse the data of the next wave of accession countries (Bulgaria, Romania and Croatia) due to the importance of corruption and poor quality of 
the legal system in that set of countries. According to the estimations, the main problem for employment in the group of accession countries is, again, the access to finance. That is the main barrier to employment creation in the private sector. Start-up costs and market regulation follow in the list. The tax burden is quite low so its impact on labor market is still quite low (as opposed to the new EU countries).

3. Ukraine and Russia suffer on average from cumbersome market regulation, which is the main cause of their relative underdevelopment with regard to private employment. Next in line is access to finance and start-up costs. 


\title{
APPENDIX 1: COUNTRY GROUPING
}

For benchmarking purposes we have grouped ECA countries in the following way:

\section{CEE (CENTRAL AND EASTERN EUROPE)}

Bulgaria

Czech Republic

Estonia

Hungary

Latvia

Lithuania

Poland

Romania

Slovakia

Slovenia

SEE (SOUTHERN AND CENTRAL EUROPE)

Albania

Bosnia i Herzegovina

Croatia

Macedonia (FRY)

Serbia and Montenegro

CIS (COMMONWEALTH OF INDEPENDENT STATES)

\author{
Armenia \\ Azerbaijan \\ Belarus \\ Georgia \\ Kazakhstan \\ Kyrgyz Republic \\ Moldova \\ Russia \\ Tajikistan \\ Turkmenistan \\ Ukraine \\ Uzbekistan
}

\section{EUROPE}

EU-15 +Norway, Switzerland and Luxemburg when available. 


\section{APPENDIX 2: INVESTMENT CLIMATE INDICATORS}

\section{Start-up cost index:}

Data come from the World Bank database "Doing Businesses". They are based on the work of Djankov, Simeon, Rafael La Porta, Florencio, Lopez-de-Silanes and Andrei Shleifer who measured the start-up costs of a new firm registered legally as a limited liability society and owned by residents in the country. Those costs include the number of procedures one has to undertake to register the business, the time the whole process takes, the minimum capital requirements and, finally, the monetary cost of the registration process. Both the costs of undertaking the process and minimum capital requirements are measured in percentage of GNI per capita.

To construct the start-up cost index we have followed the methodology used in the annual reports of the "Economic Freedom of the World" and the "Human Development Index" among others. ${ }^{13}$. Each component (procedures, time, cost and minimum capital) has been re-scaled to be between 0 and 10. Then an unweighted average has been taken to calculate the overall indicator. There is data for Europe, the US and all ECA countries, with the exceptions of Estonia, Tajikistan and Turkmenistan. ${ }^{14}$

\section{Access to finance}

The access to finance index is a summary of the following variables: ratio of domestic credit provided by deposit money to GDP (World development Indicators, World bank); interest rate spread and real interest rate (both from the Word Development Indicators, World Bank); ratio of deposit coverage to GDP, which is used by the IMF as a proxy to collateral $^{15}$; and the World Bank's measure of creditors' protection index. The later comes from the World Bank's Doing Business database. It is an indicator of creditor rights in insolvency, based on the methodology of La Porta and others (1998). The indicator measures four powers of secured lenders in liquidation and reorganization, such as priority access to the proceeds from liquidation. The aggregate creditor rights index sums the total score across all four variables. A minimum score of 0 represents weak creditor rights and the maximum score of four represents strong creditor rights.

Each of those variables has been re-scaled so the best is assigned the number 10 and the worst 0 . The overall access to finance index is a simple average of all components.

\section{Exit costs}

The World Bank's database "Doing Businesses" is one of the first attempts to measure in a comparable way the exit costs. Members of the International Bar Association's Committee on Insolvency and participating law firms or bankruptcy judges from around the world were sent a questionnaire enquiring about the number of procedures, time and cost of the process, as well as about the preservation of the priority rule to secured creditors and the efficiency of the outcome of the bankruptcy process. The index captures the summary indicator "Goals of insolvency index" which measures whether the insolvency law achieves its goals successfully. The higher the index, the more successful is the system.

\footnotetext{
${ }^{13}$ James Gwartney, Robert Lawson and Neil Emerick: Economic Freedom of the World Annual reports. The Fraser Institute, Canada.

${ }^{14}$ See appendix 1 for country grouping

${ }^{15}$ Garcia, Gillian (1999): „Deposit insurance: a survey of actual and best practices“ IMF WP/99/54
} 


\section{Market regulation}

This is an unweighted average of the credit market and labor market regulation indexes provided by the Economic Freedom of the World's Annual Report. ${ }^{16}$ The credit market regulation captures issues such as the percentage of deposits held in privately owned banks, the degree of competition from foreign banks, the extension of credit to private sector and the interest rate controls. The labor market regulation index comprises the impact of minimum wages, hiring and firing practices, union coverage and the effect of unemployment benefits on the incentives to work. Please keep in mind that the Economic Freedom of the World indexes are constructed from hard data and survey data (such as the Global competitiveness Report). Hence there is room for subjective interpretations.

\section{Quality of the legal system}

This variable results from the multiplication of the World Bank's objective information on the efficiency of the courts in enforcing contracts and the subjective evaluation of the 2003 Economic Freedom of the World of the independence from the government, impartiality and integrity of the judicial system.

The World Bank's database “Doing Business" has information on issues related to enforcing contracts derived from questionnaires answered by attorneys at private law firms. The questionnaires cover the step-by-step evolution of a debt recovery case before local courts in the country's most populous city. It covers issues such as the number of procedures required, duration and cost of process as well as an index of the procedural complexity of contract enforcement. We have summarized the four dimensions related to contract enforcement (procedures, duration, cost and complexity) in a unique index following the same methodology as before, that is, assigning a 10 to the best country, a 0 to the worst and then taking the average.

\section{Size of the government}

The size of government is approximated by the output supplied by State-operatedEnterprises and government investment as a percentage of GDP. The hard data come from the Economic Freedom of the World 2003 annual report.

\section{Corruption Perception Index}

The Corruption Perception Index is constructed by Transparency International. The data refers to 2002 and ranks the countries according to the degree in which corruption is perceived to exist among public officials and politicians. It draws on 15 different polls and surveys from nine independent institutions.

\section{The tax burden}

Tax revenue as percentage of GDP. It comes from the World Development Indicators of the World Bank.

\footnotetext{
${ }^{16}$ The following set of countries is excluded from the Economic Freedom Index: Kyrgyz Republic, Serbia and Montenegro, Bosnia, Macedonia, Kazakhstan, Uzbekistan, Moldova, Belarus, Azerbaijan, Georgia and Armenia
} 


\section{TABLES}

Table 1: Estimation results

\begin{tabular}{|c|c|c|c|c|}
\hline \multicolumn{5}{|c|}{ Type of regression: Common shocks across countries assumed } \\
\hline \multirow[b]{2}{*}{ Variable } & \multicolumn{2}{|c|}{$\begin{array}{l}\text { Service employment } \\
\text { (corrected) }\end{array}$} & \multicolumn{2}{|c|}{ Unemployment } \\
\hline & Coefficients & t-statistics & Coefficients & t-statistics \\
\hline $\begin{array}{l}\text { Shocks (given } \\
\text { average institutions) }\end{array}$ & $0.8 \%$ & & $0.85 \%$ & \\
\hline Start-up cost index & $-0.29 *$ & $(-1.45)$ & 0.09 & $(0.26)$ \\
\hline Exit cost index & -0.003 & $(-0.28)$ & -0.006 & $(-0.24)$ \\
\hline Finance index & 0.41** & $(2.95)$ & -0.18 & $(-0.42)$ \\
\hline Legal system index & -0.04 & $(-1.13)$ & -0.05 & $(-0.86)$ \\
\hline $\begin{array}{ll}\text { Mk. } & \text { Regulation } \\
\text { index } & \end{array}$ & $-0.64 * *$ & $(-2.45)$ & $1.73^{*}$ & (1.53) \\
\hline Corruption index & 0.06 & $(0.33)$ & $1.57 * *$ & (2.37) \\
\hline Tax burden & -0.08 & $(-1.11)$ & $0.43 * *$ & $(2.35)$ \\
\hline Observations & \multicolumn{2}{|c|}{106} & \multicolumn{2}{|c|}{104} \\
\hline Adjusted R-Squared & \multicolumn{2}{|c|}{0.95} & \multicolumn{2}{|c|}{0.77} \\
\hline \multicolumn{5}{|c|}{$\begin{array}{l}\text { Non-linear least square estimation } \\
* \text { significant at } 15 \% \\
* * \text { significant at } 1 \%\end{array}$} \\
\hline
\end{tabular}

Table 2: contribution of investment climate institutions to service employment change over the last decade in new EU countries

\begin{tabular}{|l|c|c|c|c|c|c|c|c|}
\hline & $\begin{array}{c}\text { Hungary } \\
(92-02)\end{array}$ & $\begin{array}{c}\text { Czech Rep. } \\
(92-02)\end{array}$ & $\begin{array}{c}\text { Slovakia } \\
(94-02)\end{array}$ & $\begin{array}{c}\text { Poland } \\
(94-02)\end{array}$ & $\begin{array}{c}\text { Latvia } \\
(96-02)\end{array}$ & $\begin{array}{c}\text { Lithuania } \\
(97-02)\end{array}$ & $\begin{array}{c}\text { Slovenia } \\
(93-02)\end{array}$ & $\begin{array}{c}\text { Average } \\
\text { new EU } \\
\text { countries }\end{array}$ \\
\hline $\begin{array}{l}\text { Actual change in } \\
\text { service employment, } \\
\text { in \% }\end{array}$ & 1.11 & 3.78 & 0.66 & 1.33 & 1.89 & -1.83 & 0.61 & 1.08 \\
\hline $\begin{array}{l}\text { Predicted change by } \\
\text { the model in service } \\
\text { employment, in \% } \\
\text { Of which: }\end{array}$ & 1.92 & 1.41 & 0.42 & 1.51 & 1.26 & 0.13 & 0.98 & 1.09 \\
\hline $\begin{array}{l}\text { Time shock } \\
\text { Start-up costs }\end{array}$ & -0.57 & -0.15 & -0.16 & -0.26 & 0.17 & 0.03 & 0.02 & -0.13 \\
\hline Access to finance & 0.70 & 0.43 & 0.02 & 0.52 & 0.39 & -0.02 & 1.03 & 0.44 \\
\hline Market regulation & 1.00 & 0.24 & -0.36 & 0.06 & 0.14 & -0.01 & -0.53 & 0.08 \\
\hline Tax burden & -0.63 & -0.44 & -0.16 & 0.11 & 0.12 & 0.04 & -0.87 & -0.26 \\
\hline
\end{tabular}

Note that only the significant variables from table 1 have been included in table 2 
Table 3: contribution of investment climate institutions to service employment change over the last decade in accession countries, Russian and Ukraine

\begin{tabular}{|l|c|c|c|c|c|c|c|}
\hline & $\begin{array}{c}\text { Romania } \\
(94-02)\end{array}$ & $\begin{array}{c}\text { Bulgaria } \\
(90-01)\end{array}$ & $\begin{array}{c}\text { Croatia } \\
(96-02)\end{array}$ & $\begin{array}{c}\text { Average } \\
\text { next } \\
\text { wave }\end{array}$ & $\begin{array}{c}\text { Ukrania } \\
(90-02)\end{array}$ & $\begin{array}{c}\text { Russia } \\
(92-00)\end{array}$ & $\begin{array}{c}\text { Average } \\
\text { Russia- } \\
\text { Ukraine }\end{array}$ \\
\hline $\begin{array}{l}\text { Actual change in } \\
\text { service employment }\end{array}$ & -0.08 & 2.89 & 0.36 & 1.06 & & & \\
\hline $\begin{array}{l}\text { Predicted change by the } \\
\text { model in service } \\
\text { employment. Of which: }\end{array}$ & 0.30 & 1.64 & 0.33 & 0.76 & 0.42 & 0.36 & 0.39 \\
\hline Time shock & 1.08 & 0.92 & 0.44 & 0.81 & 0.81 & 0.81 & 0.81 \\
\hline Start-up costs & 0.53 & 0.16 & -0.01 & 0.23 & -0.49 & 0.18 & -0.16 \\
\hline Access to finance & -1.75 & 0.34 & -0.08 & -0.50 & -0.19 & -0.31 & -0.25 \\
\hline Market regulation & 0.06 & 0.05 & 0.34 & 0.15 & -0.06 & -0.64 & -0.35 \\
\hline Tax burden & 0.37 & 0.16 & -0.35 & 0.06 & 0.36 & 0.31 & 0.34 \\
\hline
\end{tabular}

Table 4: importance of institutions by region

\begin{tabular}{|c|c|c|c|}
\hline $\begin{array}{c}\text { Ranking of institutions by order of } \\
\text { importance }\end{array}$ & $\begin{array}{c}\text { New EU } \\
\text { members }\end{array}$ & $\begin{array}{c}\text { Next accession } \\
\text { wave }\end{array}$ & $\begin{array}{c}\text { Russia and } \\
\text { Ukraine }\end{array}$ \\
\hline 1 & Access to finance & Access to finance & Market regulation \\
\hline 2 & Tax burden & Start-up costs & Access to finance \\
\hline 3 & $\begin{array}{c}\text { Start-up costs } \\
\text { regulation }\end{array}$ & Market regulation & Start-up costs \\
\hline 4 & Tax burden & Tax burden \\
\hline
\end{tabular}

Table 5: Contribution of institutions to unemployment increase according to a model with common shocks and a model with identified (transition) shock

\begin{tabular}{|c|c|c|}
\hline \multicolumn{3}{|c|}{ Unemployment Regression } \\
\hline Hungary & $\begin{array}{l}\text { Regression } \\
\text { with time } \\
\text { dummies }\end{array}$ & $\begin{array}{l}\text { Regression } \\
\text { with } \\
\text { transition } \\
\text { shock }\end{array}$ \\
\hline $\begin{array}{l}\text { Actual change in } \\
\text { unemployment }\end{array}$ & -3.5 & -3.5 \\
\hline $\begin{array}{l}\text { Predicted change by } \\
\text { the model in } \\
\text { unemployment. Of } \\
\text { which: }\end{array}$ & -1.5 & -2.1 \\
\hline Shock & 1.9 & 3.8 \\
\hline Access to finance & -3.4 & -8.2 \\
\hline $\begin{array}{l}\text { Government } \\
\text { interference }\end{array}$ & -3.9 & -4.9 \\
\hline Tax burden & 3.8 & 7.2 \\
\hline
\end{tabular}




\section{FIGURES}

Figure 2.1: Subjective perception of how easy (or difficult) is to start a business



Source: Global Competitiveness Report (2002)

Figure 2.2: Bribes are rarely needed to obtain business licenses

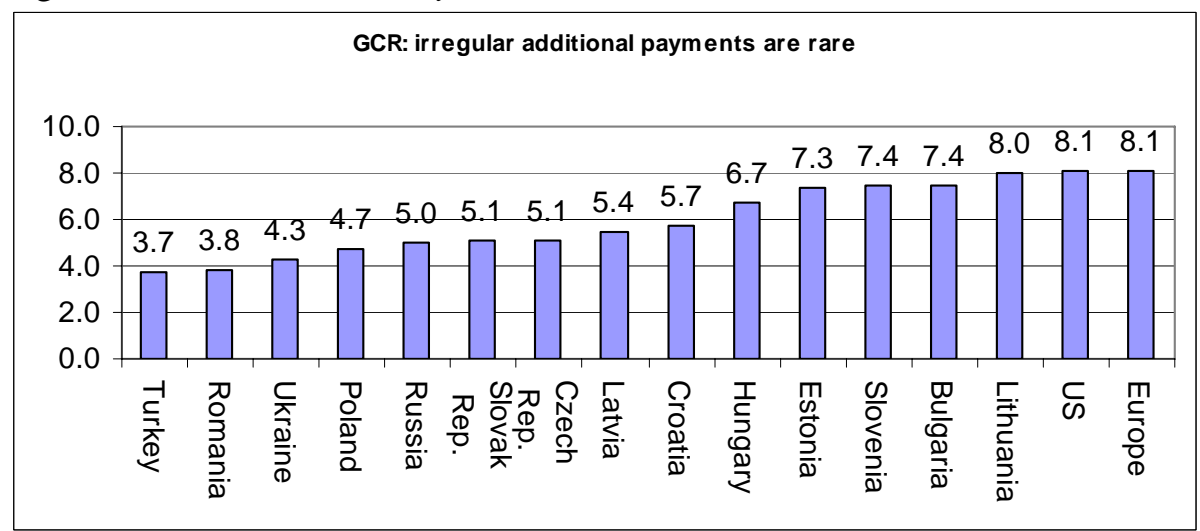

Source: Global Competitiveness Report (2002)

Figure 2.3: Ranking of countries according to the efficiency of courts to enforce contracts

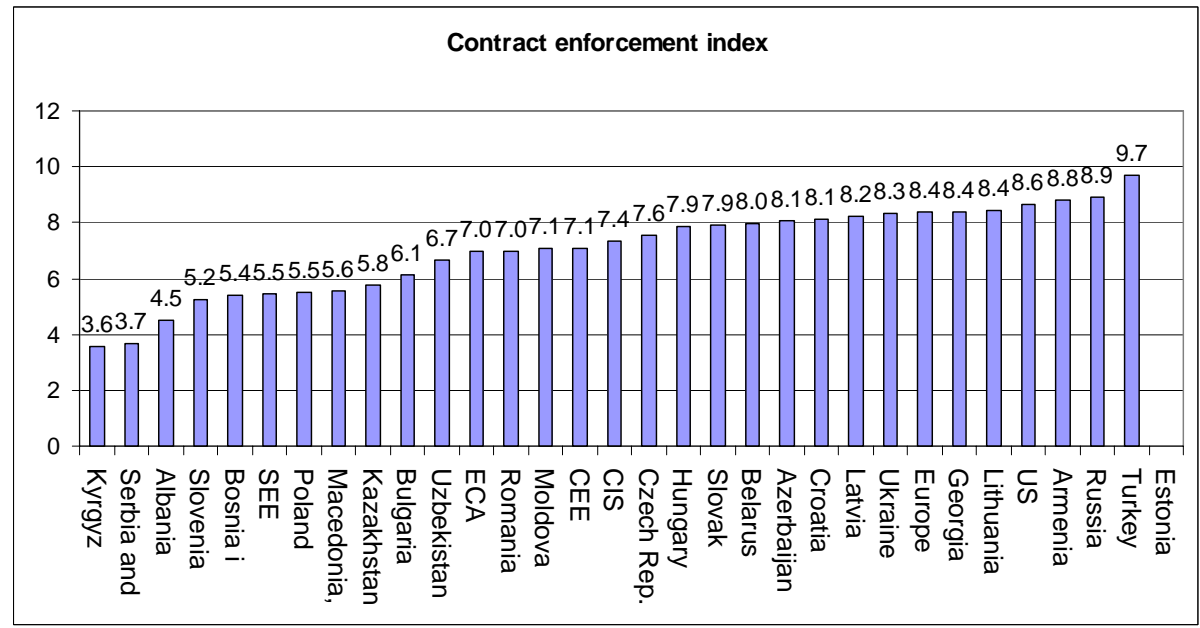

Source: World Bank, Doing Business Database; Bank staff calculations 
Figure 2.4: However efficient, courts do not have to be necessarily independent

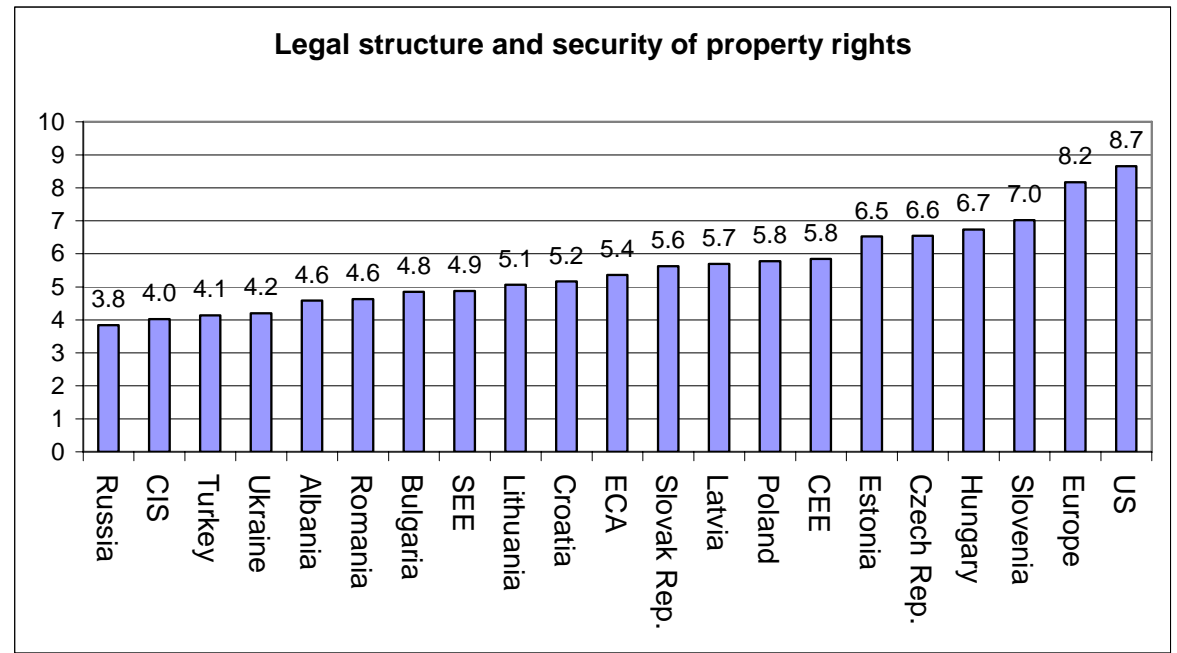

Source: Economic Freedom of the World, 2003 Annual Report 
Figure 3.1: High government interference in the economy is compatible with high employment rate

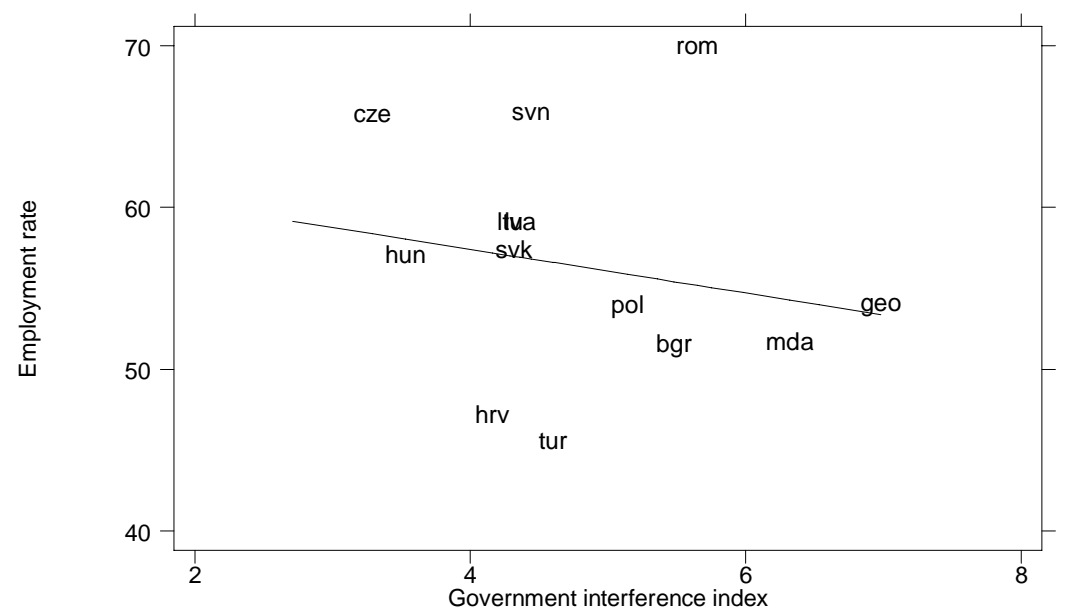

Figure 3.2: The reason is that public employment does not respond to the investment climate. Instead, if service employment is plotted against government interference, a clear negative relation is found.




Figure 3.3: Employment outcomes are better in countries with better access to finance

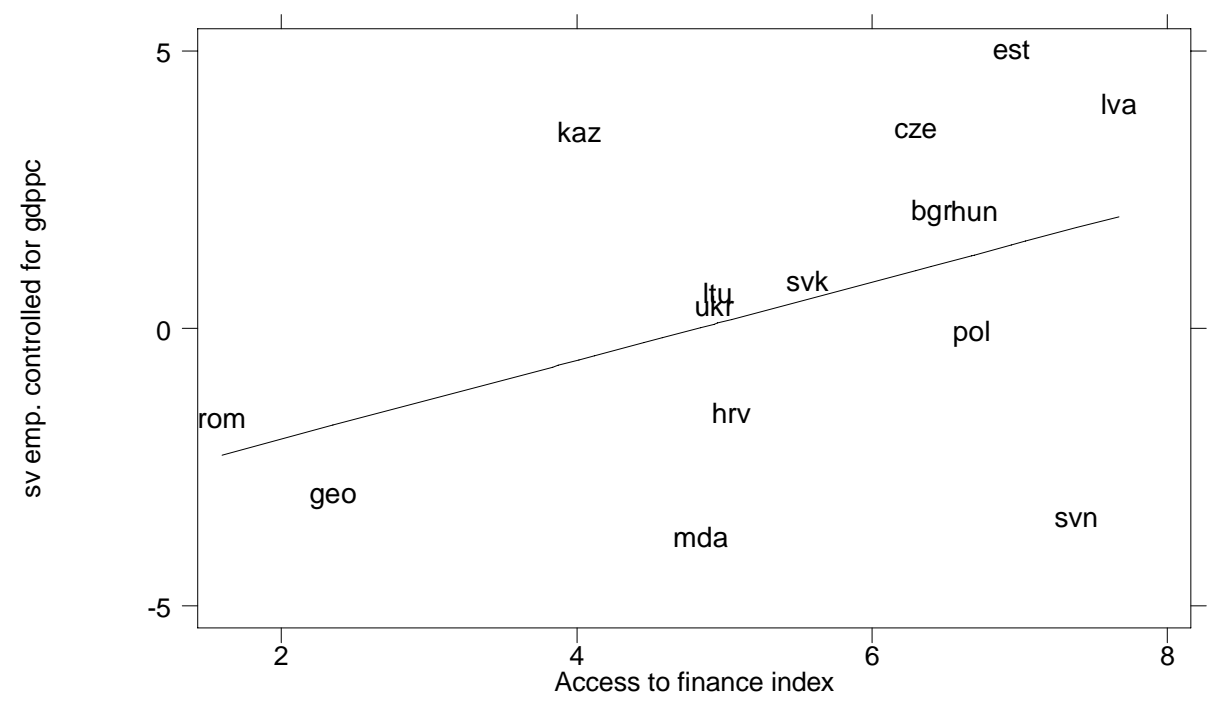

Figure 3.4: The real interest rate or cost of credit is the most important variable within the access to finance dimension

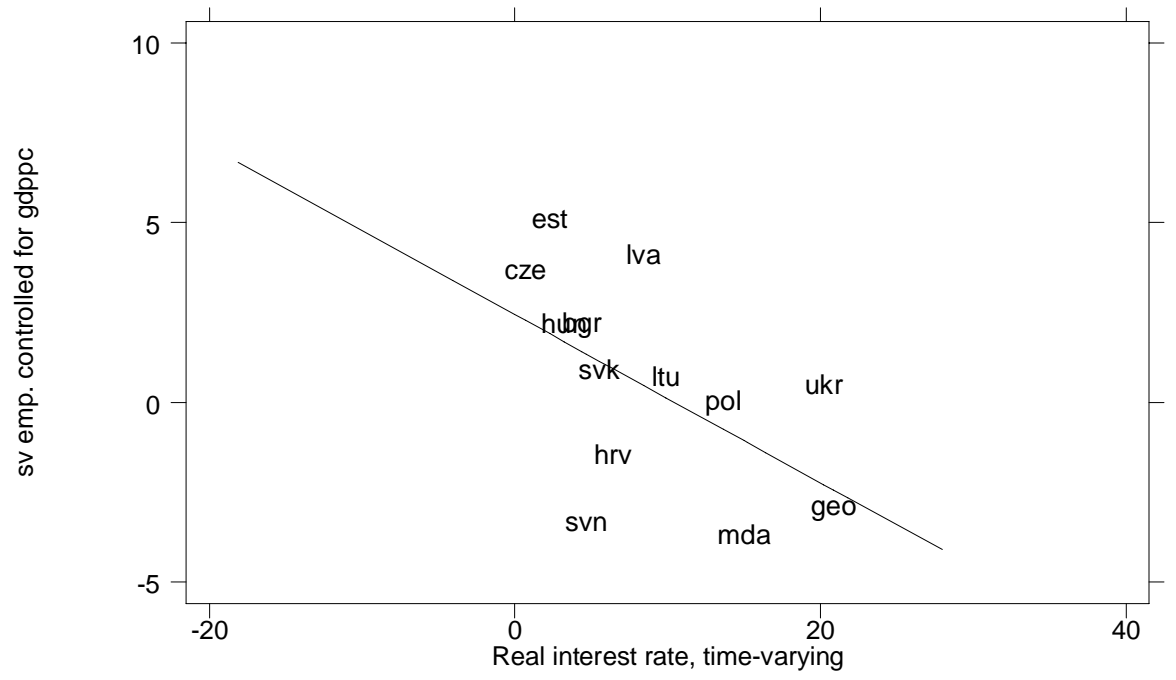


Figure 3.5: Employment outcomes are better in countries where government does not interfere into business activities.

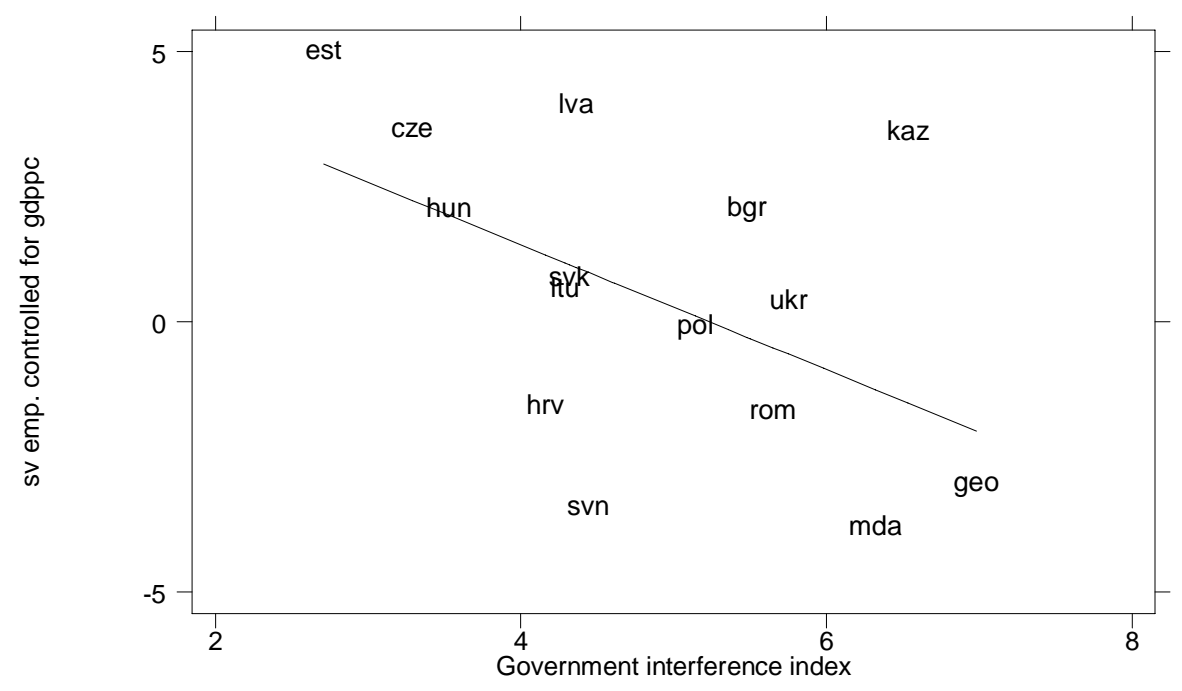

Figure 3.6: The quality of the legal system is one very important aspect of government interference. More efficient and independent judicial system is good for employment.

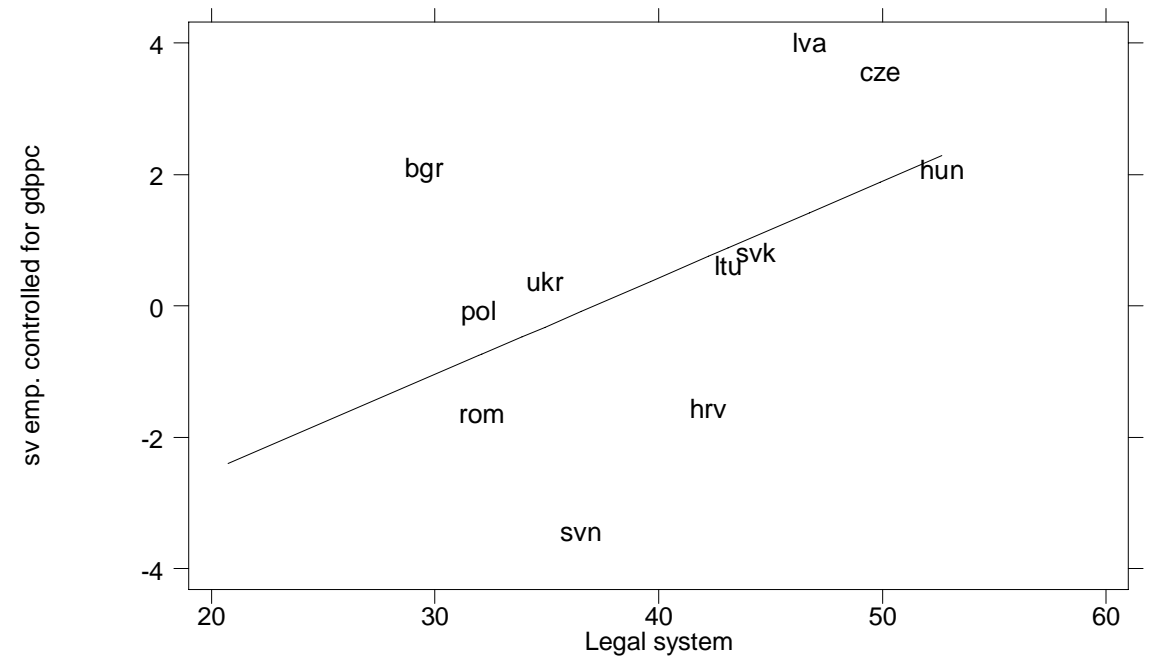


Figure 3.7: Excessive market regulation hurts job creation

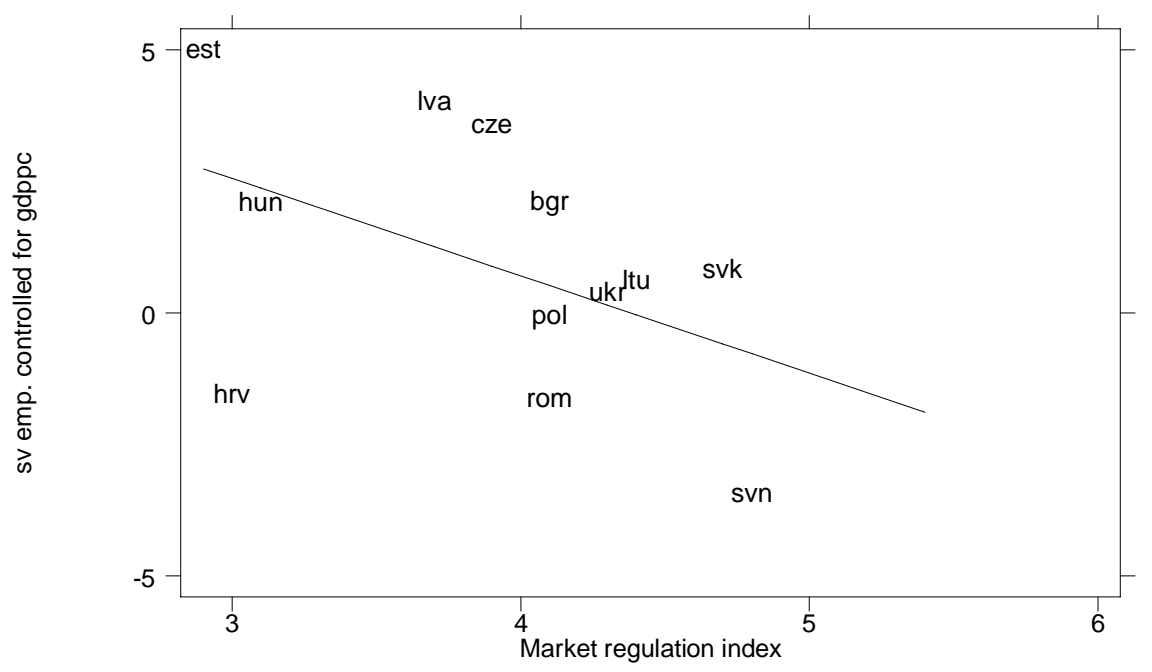


Figure 4.1: While firm formation is key for job creation, starting a business is not easy in many ECA countries

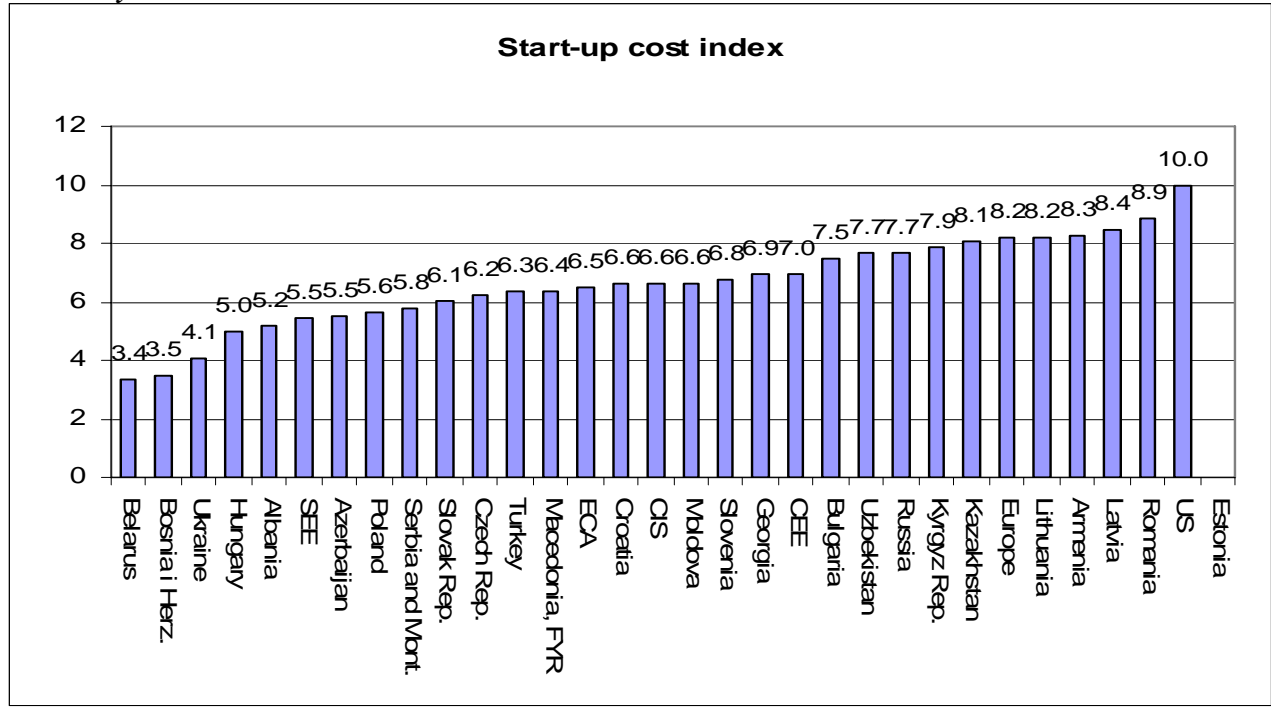

Source: World Bank, Cost of Doing Business Database (2003); and Bank staff calculations

Figure 4.2: Good access to finance is one of the main contributors to a good employment performance

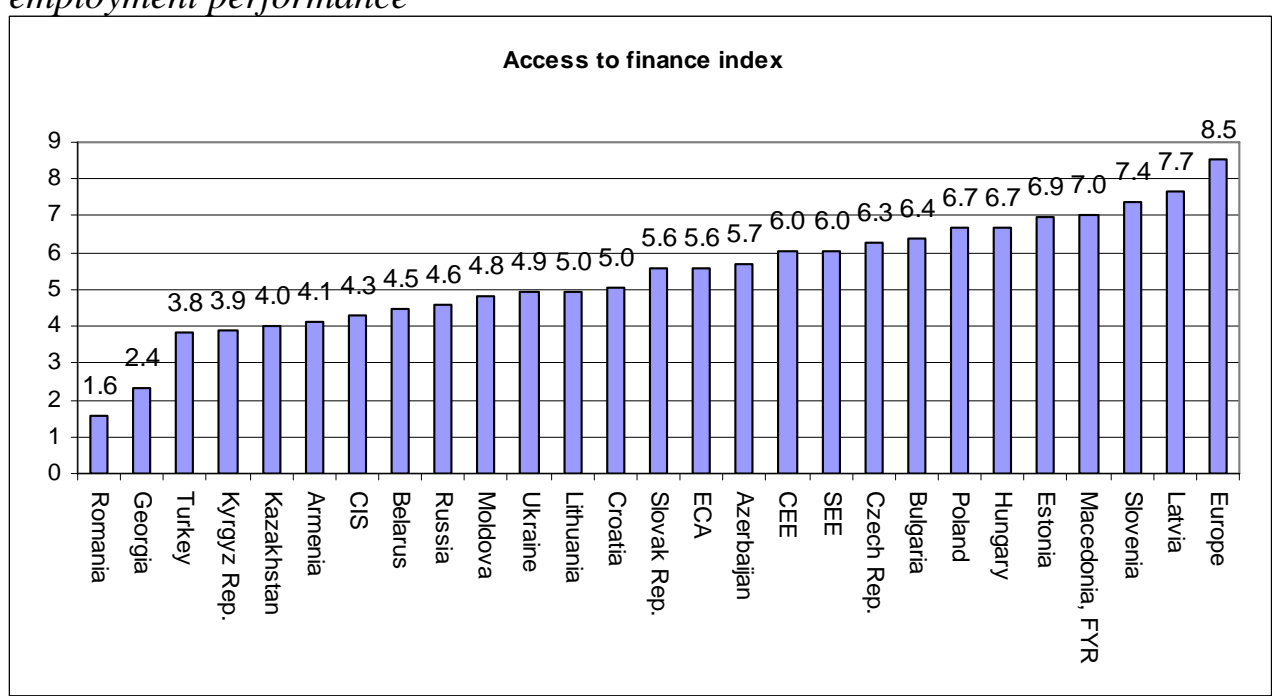

Source: World Bank, World Development Indicators (2002); IMF WP/99/54; and Bank staff calculations. 
Figure 4.3: Markets in ECA tend to be overregulated which is likely to hamper job creation

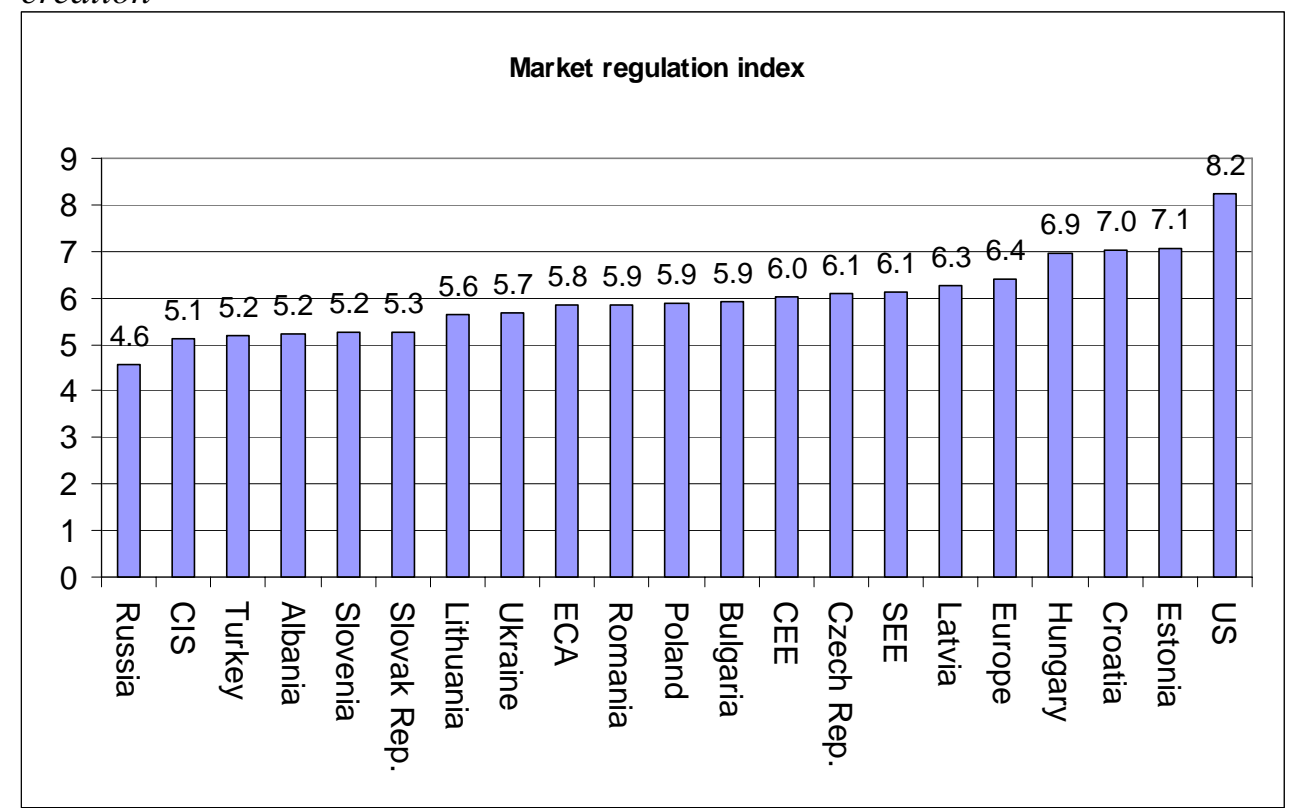

Source: Economic Freedom of the World 2003; Bank staff calculations.

Figure 4.4: Corruption is high in ECA raising the costs of doing business and inhibiting

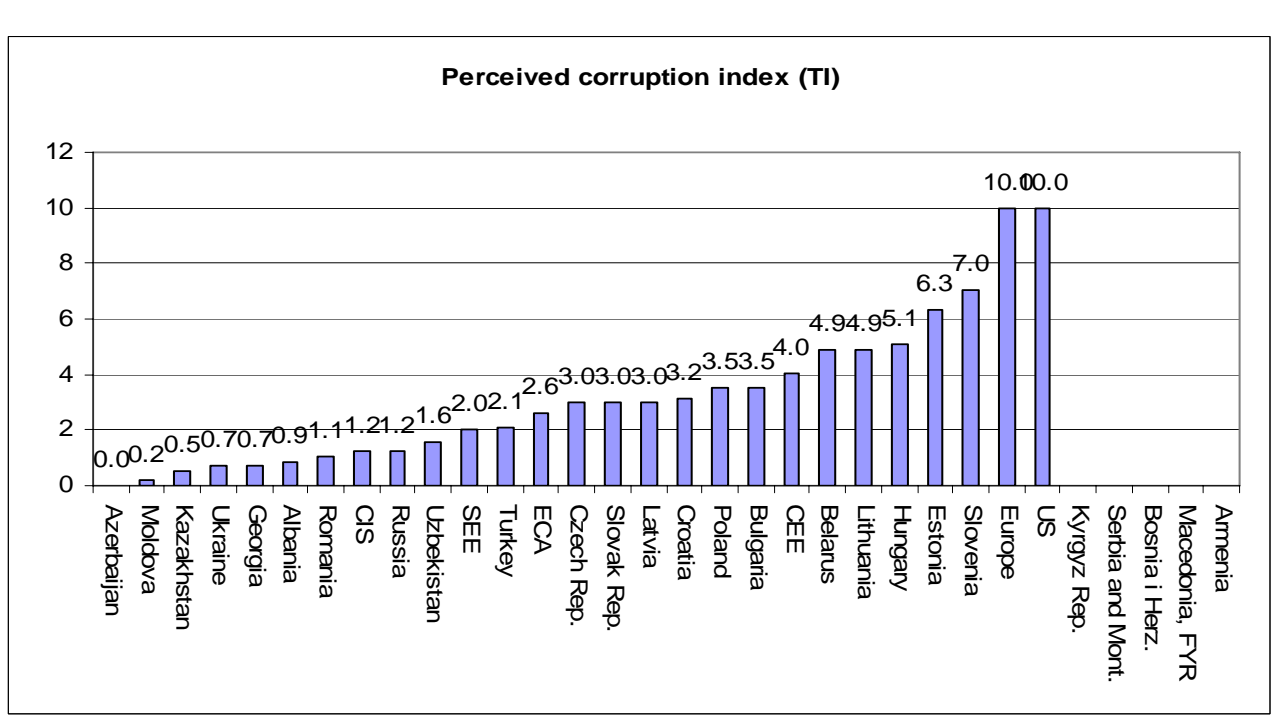

job

creati

on

Source: Transparency International (2002) 
Figure 4.5: The tax burden becomes a problem to firm survival and growth as countries advance in their transition to a market economy

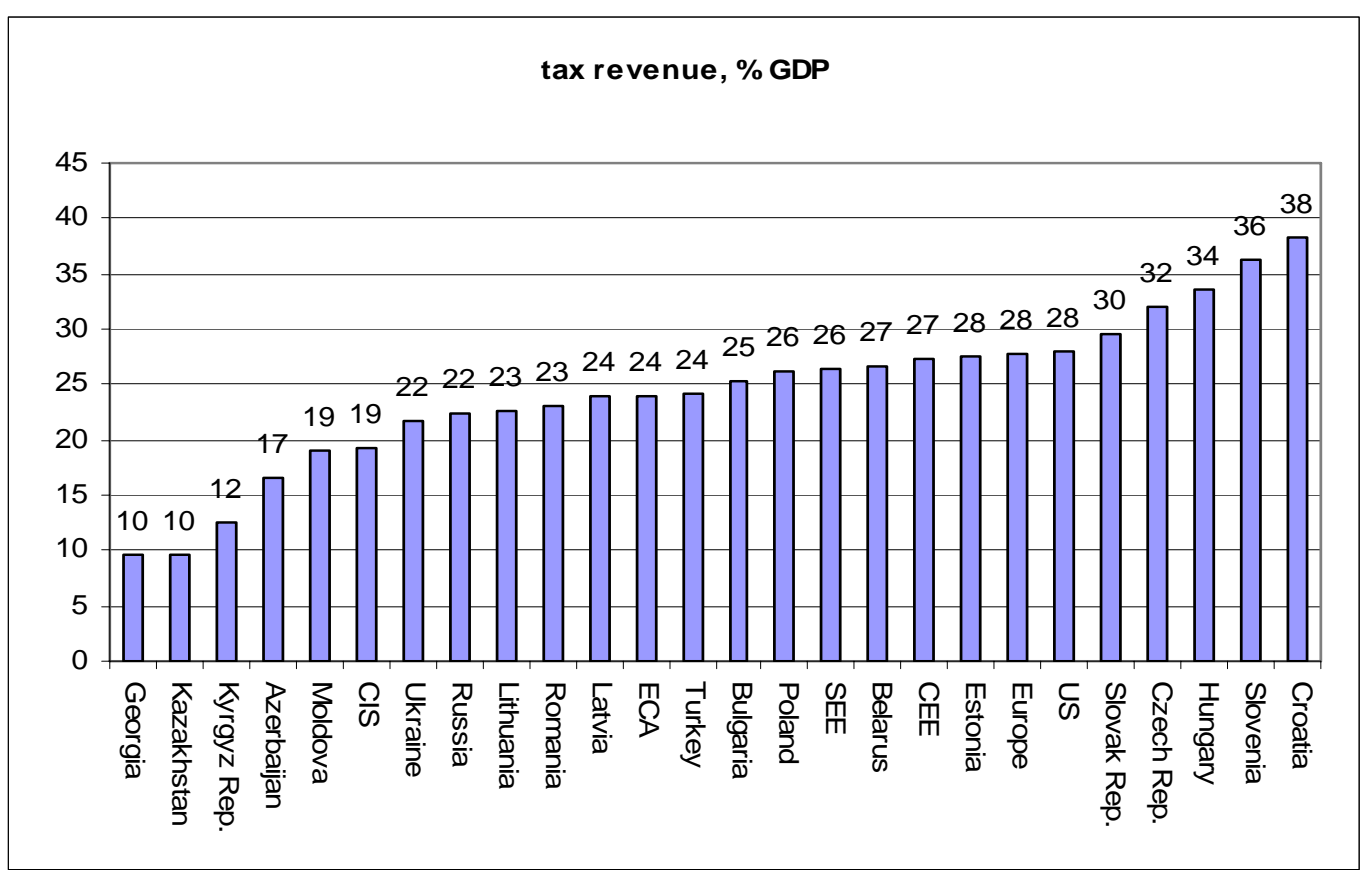

Source: World Bank, World Development Indicators (2002)

Figure 4.6: ECA countries lag behind as regards the efficiency of independence of the judicial system and protection of property rights

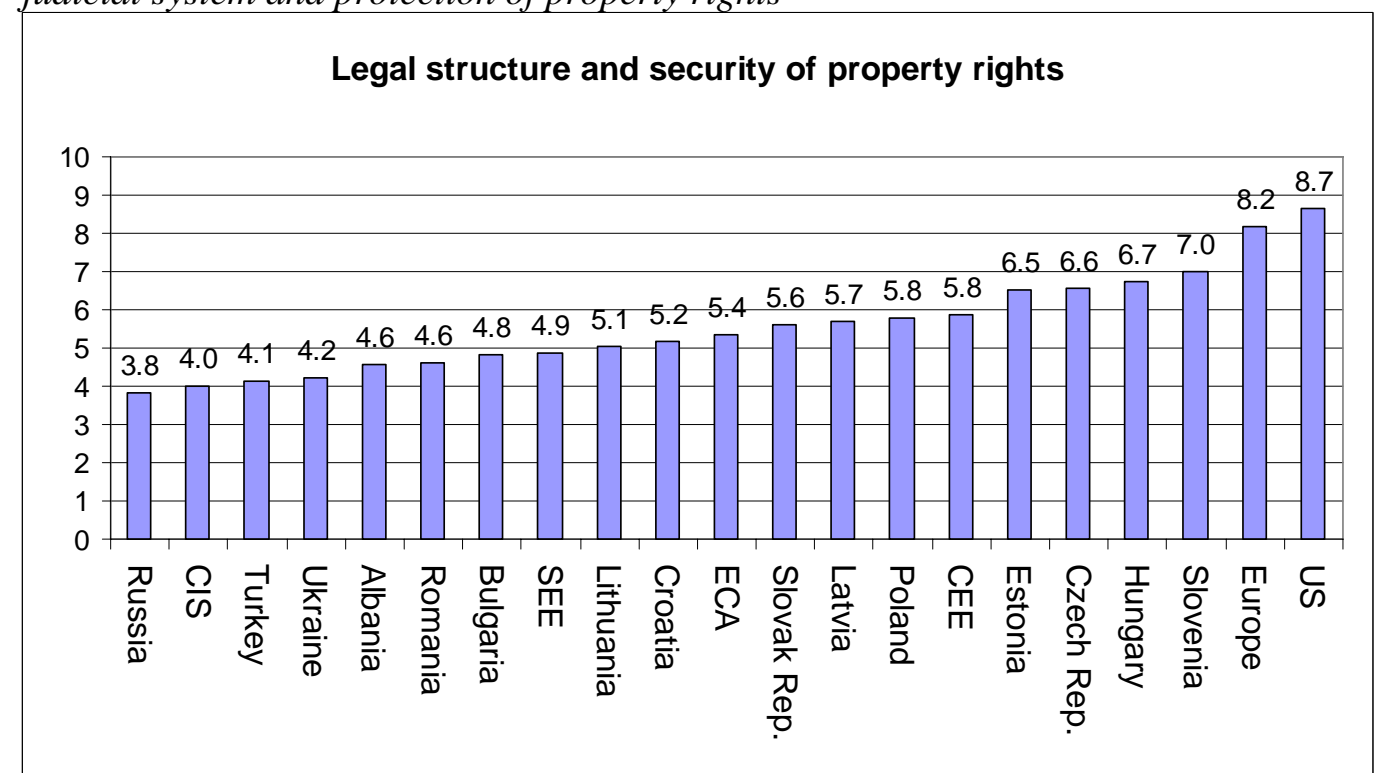

Source: Economic Freedom of the World (2003) 